\title{
A Regional Assessment of Bilingual Programmes in Primary and Secondary Schools: the Teachers' Views
}

\author{
RAMIRO DURÁN-MARTÍNEZ \\ Fernando Beltrán-Llavador \\ University of Salamanca
}

Received: 30 May 2014 / Accepted: 3 March 2015

ISBN: $1697-7467$

\begin{abstract}
This article analyses the teachers' assessment of bilingual sections in Castile and León's schools after seven years of implementation. Results are drawn from the analysis of a questionnaire filled out by 151 teachers on three dimensions: training, teaching resources, and impact of the initiative. Our study reveals that the teachers' high degree of satisfaction concerning initial training is not incompatible with their perceived need for continuous professional development. Amongst the most profitable areas of investment, international links are ranked first. In spite of its costs, $92 \%$ consider bilingual sections a worthwhile educational initiative with manifold benefits for the school community.
\end{abstract}

Keywords: Bilingual Programmes, CLIL, Assessment, Teachers, Training.

Una evaluación regional de los programas bilingües en Primaria y Secundaria: la visión del profesorado

RESUMEN: Este artículo analiza la evaluación, por parte del profesorado, del programa de secciones bilingües en centros de Castilla y León siete años después de su implantación. Ofrece resultados extraídos de un cuestionario completado por 151 profesores sobre tres dimensiones: formación, recursos docentes y evaluación del proyecto. Nuestro estudio revela que su satisfacción respecto a la formación inicial no se contradice con la necesidad expresada de seguir formándose. Respecto a la inversión prioritaria, los vínculos internacionales ocupan el primer lugar. Pese a sus costes, un $92 \%$ de profesores evalúa positivamente dicho programa, por reportar múltiples beneficios para la comunidad escolar.

Palabras clave: Programas Bilingües, AICLE, Evaluación, Profesorado, Formación.

\section{INTRODUCTION}

There is a growing tendency in European schools to integrate foreign language and subject content teaching (House, 2007). Since the last decade CLIL has been part of mainstream education in the majority of European countries at primary and secondary levels (Eurydice, 2006). In 1996 the Ministry of Education and Science and the British Council signed an agreement to pioneer an integrated curriculum in Spanish state-run schools. Early bilingual 
education was established in 43 schools with over a thousand pupils aged three and four. Since then bilingual education has been introduced from age three through sixteen in the project schools (Dobson, Pérez and Johnstone, 2010) parallel to a steady introduction of CLIL after albeit not identical to the pioneering Bilingual Education Project (Dobson, Pérez and Johnstone, 2011). For the sake of clarification, we will adhere to an understanding of CLIL as "an umbrella term covering a dozen or more educational approaches: eg, immersion, bilingual education, multilingual education, language shower and enriched language programmes" (Mehisto, Marsh and Frigols, 2008: 12).

After the British Council/MEC agreement, most autonomous communities in Spain started to regulate bilingual education, spreading the model throughout the country. In 2006, education authorities in Castile and León authorized the creation of so-called school bilingual sections through the Order EDU/6/2006 and its subsequent modifications: Order EDU/1847/2007 and Order EDU/392/2012. In the academic year 2006-2007 a total of 74 schools introduced them; two years later, in 2008-2009, the number had increased to 115 . The Order EDU/154/2013 recently authorized an additional group of 46 schools to start a bilingual section so that in the academic year 2013/2014 Castile and León reached a total of 444 primary and secondary schools with an official offer of content and language integrated programmes. The result is that English is no longer taught only as a stand-alone subject but also as the vehicle through which a minimum of two non-linguistic subjects and a maximum of three are taught, with a foreign language use limit in the classroom of up to $50 \%$ of the pupils' school timetable. The bilingual programme is first introduced at the beginning of primary education and then subsequently through the primary and secondary education levels.

For teachers in Castile and León to be involved in CLIL programmes a CEFR B2 language accreditation has been required since 2012 (Resolution 7 November 2013), even if when they were first launched a B1 level was sufficient, while in the neighbouring community of Madrid only teachers with an accredited C1 level of English can teach in bilingual schools. And whereas in Madrid teachers were required to complete a three-month training to participate in the project (Fernández and Halbach, 2011), teachers in Castile and León were offered several training options on a voluntary basis. The main programmes were delivered by the four public universities of Castile and León and comprised 60-hour courses on communicative linguistic competence for non-specialists bilingual teachers and two postgraduate courses, namely, a 300 -hour specialisation in bilingual or CLIL teaching in English, and a 60-ECTS Master in Bilingualism (Durán and Beltrán, 2013), in addition to a continuing education plan designed by the community of Castile and León educational authority for CLIL teachers both in their schools and during intensive two-week summer courses in the United Kingdom.

\section{AIMS}

After having piloted the scheme and once different regional educational administrations decided to expand the bilingual programme to a significant percentage of schools, the time seems ripe to assess the outcomes of the initiative. This article seeks to describe how inservice primary and secondary teachers of Castile and León participating in the bilingual project perceive its effectiveness so far from three different angles, namely training before and during involvement in the project, teaching resources and the educational impact of 
the project as a whole. From the analysis of this information we will draw conclusions to improve the development of the bilingual programmes currently running in Castile and León.

Our research will thus fill a gap in the field of studies on the development of CLIL in Spain by offering a first summary report for the autonomous community of Castile and León similar to others recently published on the communities of Andalusia (Bruton, 2011; Lasagabaster and Ruiz de Zarobe, 2010; Pavón and Rubio, 2010; Lorenzo, Casal and Moore, 2009), Catalonia, Basque Country, Galicia and La Rioja (Lasagabaster and Ruiz de Zarobe, 2010), Murcia (Lova, Bolarín and Porto, 2013) and the Madrid Region (Fernández and Halbach, 2011; Laorden and Peñafiel, 2010; Pena and Porto, 2008; Fernández, Pena, García and Halbach, 2005). This will contribute to lay the foundations for further studies which may benefit from the comparison of CLIL as it is being implemented in Castile and León and in other regional areas of Spain as well as in other countries in Europe.

\section{Methodological aspects}

\subsection{Instruments}

In order to carry out our research a questionnaire was used, adapted from the one designed by Fernández and Halbach (2011) for a study prior to ours in the Madrid area. Both the content and the wording of some items were deliberately adapted to our research needs and teaching context. A Likert Scale (1/5) served to measure the response to these items, and CEFR levels were adopted for language proficiency self-assessment purposes. Finally, an open question was introduced at the end of each section of the questionnaire to give participants the opportunity to comment on the strengths and weaknesses of the programme, and to offer suggestions for improvement. Standard procedures were followed prior to the application of the questionnaire to validate it: a final draft was sent to a group of fifteen teachers participating in this research as subjects. They were asked both to provide feedback on aspects such as the clarity and relevance of the questions, and on the suitability of the possible answers, as well as to offer suggestions in order to avoid possible deficiencies.

After a section aimed at drawing contextual information about the schools and factual data on the teachers' course and cycle assigned posts, their teaching experience prior to and during their participation in a bilingual project, and their level of English and training provided for the bilingual programmes, the questionnaire addressed the following areas:

- Training: comprising questions on the level of satisfaction with their training before their involvement in the project, perceived educational needs once the project is started, specific teaching competences required, and the areas where language assistants collaborate.

- Teaching resources: seeking to know about teachers' priorities within a range of possible areas of investment such as ICT, teaching materials, support staff, international links, and levels of satisfaction with the institutional provision of educational resources.

- Overall assessment of the project: asking teachers to evaluate the global impact of the bilingual section on the students, the teachers and the school. 
A SPSS (21.0) tool for Descriptive Statistics was used, which allowed us to map the data and synthesize the answers of the questionnaire through tables so as to highlight the most salient results after a calculation of the standard measures of the central tendencies (mean) and of dispersion (standard deviation).

\subsection{Procedure and subjects}

The questionnaire was mainly sent during the month of May of 2013 to the institutional e-mail address of all Primary and Secondary schools in Castile and León that had started a bilingual section before the academic year 2011/2012 so that only those with a minimum experience of two years were included. This information was gathered from an institutional guide published by the regional educational authority including information about the educational offer available in the region (Consejería de Educación, 2010). Out of the 397 mails forwarded, which gave access to a link to the questionnaire, 315 acknowledged their receipt. The survey was completed through the cloud storage service Google Drive.

The response rate was $34.6 \%$, that is, 151 teachers from 109 different schools filled out the questionnaire: $73 \%$ were women, $82 \%$ were infant and primary education teachers and $18 \%$ were secondary teachers, who responded in fewer numbers. The survey covered both state-run and state-subsidised schools in rural and urban areas. All participants in this study had at least one year of experience in the teaching of non-linguistic subjects in English. Their overall teaching experience ranged from 1 to 38 years with a mean number of 12 years in the teaching profession. As for the number of years involved in bilingual sections the mean was 3.52 within a range of 1 to 14 years, including teachers who had worked in the British Council/MEC project from the outset. From these data we can conclude that even if the group is relatively young, their teaching experience in bilingual sections is already grounded.

When asked to evaluate their level of English, $39 \%$ rated it as advanced $(\mathrm{C} 1$ or $\mathrm{C} 2)$, $51 \%$ as intermediate (B2) and only $10 \%$ admitted having the minimum B1 language level requirement to participate in the programme when it was first launched, a level which after the year 2012 falls below the access requirement.

As for the kind of training received to partake in bilingual programmes, 55\% stated that they had undergone some specific formation. This was very varied in length and content, ranging from postgraduate specialist and master courses designed for CLIL teaching to courses on methodological aspects of CLIL offered by Castile and León Education Department. Other training formats included two-week summer courses abroad, one-week intensive courses held in the autonomous community and Comenius life-long learning bilingual education programmes.

\section{Results}

\subsection{Training}

In spite of many commonly perceived drawbacks, teachers still see CLIL as "an inspirational challenge", even if "there is a great disparity regarding the circumstances in which teachers are teaching" (Lasagabaster and Ruiz de Zarobe, 2010: 269). Such disparity is first 
and foremost reflected in their training profiles and CLIL journeys. Thus, the first question of the survey is concerned with the teachers' perception of their training prior to being fully engaged in the project. The mean result is $3.79(n=151$, Sd. 0.46$)$ with a significant $26 \%$ of teachers expressing complete satisfaction and $63 \%$ satisfaction-to-high satisfaction levels. In their study on the autonomous community of Madrid, having obtained a statistically similar response concerning initial training, Fernández and Halbach hold that this perception "is in part contradicted by the large number of training needs they mention in the next question" (2011: 246). However, the recognition of a sufficient initial training does not seem to contradict a perceived need for further training, which is to be expected from members of a profession which demands continuous updating (Boldizsár, 2003), particularly at a time of dramatic changes and in the face of challenging educational scenarios such as the very introduction of bilingual programmes in mainstream education.

Table I. Percentage of frequency of teaching competences and teacher's training needs $(n=151) .1$ equals not important and 5 equals very important.

\begin{tabular}{|c|c|c|c|c|c|c|c|}
\hline \multicolumn{8}{|c|}{ Teaching competences needed to become an active member of the bilingual programme } \\
\hline & 1 & 2 & 3 & 4 & 5 & Mean & $\begin{array}{l}\text { Standard } \\
\text { Deviation }\end{array}$ \\
\hline Linguistic Competence & 0 & 0 & 2 & 27 & 71 & 4.69 & 0.51 \\
\hline Didactic Competence & 0 & 0 & 3 & 28 & 69 & 4.67 & 0.53 \\
\hline Subject Content Knowledge & 0 & 2 & 8.5 & 53.5 & 36 & 4.24 & 0.68 \\
\hline $\begin{array}{l}\text { Content and Language Integration } \\
\text { Competence }\end{array}$ & 0 & 0 & 5 & 35 & 60 & 4.58 & 0.58 \\
\hline \multicolumn{8}{|c|}{ Teacher's training needs } \\
\hline & 1 & 2 & 3 & 4 & 5 & Mean & $\begin{array}{l}\text { Standard } \\
\text { Deviation }\end{array}$ \\
\hline Methodology & 5 & 9 & 23 & 39 & 24 & 3.66 & 1.01 \\
\hline English language & 14 & 26 & 21 & 26 & 13 & 2.99 & 1.26 \\
\hline Teaching materials design & 4 & 16 & 24 & 38 & 18 & 3.50 & 1.01 \\
\hline Learning to locate resources & 5 & 20 & 26 & 33 & 16 & 3.36 & 1.11 \\
\hline Using ICT & 7 & 23 & 31 & 23 & 16 & 3.18 & 1.17 \\
\hline Teaching and practice of Literacy & 6 & 15 & 28 & 29 & 19 & 3.41 & 1.12 \\
\hline Teaching and practice of Oracy & 7 & 17 & 21 & 35 & 20 & 3.44 & 1.18 \\
\hline $\begin{array}{l}\text { Content subject teaching through } \\
\text { English }\end{array}$ & 6 & 21 & 26 & 29 & 18 & 3.33 & 1.17 \\
\hline
\end{tabular}


Our questionnaire, based on Fernández and Halbach (2011), asked teachers to rank the competences they considered necessary to become effectively active members of the bilingual project: Linguistic, Didactic, Subject Content Knowledge, and Content and Language Integration. Table I shows that teachers consider the four components extremely and almost equally relevant, the answers to this dimension showing a mean of $4.54(n=151, \mathrm{Sd} .0 .37)$, with "Subject Content Knowledge" being slightly less valued. This is consistent with the way they qualify their answers adding passionate comments on the absolute need to reach a proficient level of language for the CLIL programmes to succeed and for them to feel fully confident in the integrated teaching of language and subject content. Good will may be decisive but it certainly does not suffice, and teachers express an eagerness to continue their formation and wish they were given further chances to participate in immersion programmes abroad not only once every five years, as required by the educational authority, since this is considered key to improving their performance.

In the answers to the third question, Areas where you need training once the project has been implemented, with an average result of $3.36(\mathrm{n}=151, \mathrm{Sd} .0 .84)$, however, a significant shift in training priorities is worth noting: together with methodology, linguistic training was initially considered the most important teaching competence and the foremost prerequisite to become apt members of the bilingual project (4.69) but once the project has started, it falls behind the others (2.99) while methodological training (3.66) is still perceived as vital to the success of the project, followed by the design of teaching materials (3.50). These data suggest that when the linguistic proficiency is granted, linguistic training remains in the background whereas methodological concerns, closely linked to the teaching of oracy and literacy, still constitute a day-to-day priority for teachers who demand very practical responses to endless specific needs emerging within very different classroom settings.

Once again, our analysis confirms the need for teachers to create context-bound materials to meet manifold and very diverse content and language objectives. Locating resources, creating specific materials and resorting to ICT-based activities and multimodal deliveries of lessons are largely interdependent and also require specific needs analysis and course design competences.

As for the role of language assistants in Bilingual Programmes, this is diverse in the different regions of Spain. In some of them, such as Madrid, language assistants are considered a key element of the programme, with 1.122 of them in the year 2012/2013 (Consejo Escolar de la Comunidad de Madrid, 2013). Whereas in Madrid, they are appointed through agreements with both the Ministry of Education and the Fulbright Commission, in Castile and León they are just recruited by the yearly official announcement of the Ministry of Education. The data of our analysis show that in Castile and León only 32 teachers (21 \%) reported having a language assistant to support their work in CLIL classrooms. In their comments to the questionnaire, teachers complained, in fact, about the lack of native speakers and the scarcity of language assistants. 
Table II. Percentage of areas where language assistants collaborate $(n=32)$.

1 equals not important and 5 equals very important

\begin{tabular}{|l|c|c|c|c|c|c|c|}
\hline & $\mathbf{1}$ & $\mathbf{2}$ & $\mathbf{3}$ & $\mathbf{4}$ & $\mathbf{5}$ & Mean & $\begin{array}{c}\text { Standard } \\
\text { Deviation }\end{array}$ \\
\hline Teaching materials design & 52 & 24 & 7 & 14 & 3 & 1.93 & 1.22 \\
\hline Locating resources & 31 & 31 & 21 & 17 & 0 & 2.24 & 1.09 \\
\hline English & 3 & 7 & 7 & 33 & 50 & 4.20 & 1.06 \\
\hline Use of ICT & 30 & 34 & 23 & 13 & 0 & 2.20 & 1.03 \\
\hline Teaching and practice of Literacy & 17 & 10 & 35 & 17 & 21 & 3.14 & 1.35 \\
\hline Teaching and practice of Oracy & 7 & 13 & 7 & 40 & 33 & 3.80 & 1.24 \\
\hline Subject content teaching in English & 27.5 & 24 & 13.5 & 21 & 14 & 2.69 & 1.44 \\
\hline
\end{tabular}

Language assistant activities, regulated in the Orders EDU/1134/2011 and EDU/277/2014, include fostering oral conversation in the target language, offering models of pronunciation and grammar, assisting the teacher in the production of didactic resources and bringing into the classroom cultural aspects about the countries where the foreign language is spoken. Apart from the scant number of language assistants, our data show that their presence is far from being optimized (this dimension has a mean of 2.50, $n=32, \mathrm{Sd} .0 .43$ ), as their main function is perceived almost exclusively as a source of native language input in the classroom (4.20), more marked in the area of oracy (3.80) than in that of literacy (3.14). They also reveal a very scarce use of the language assistant in other teaching areas: teaching materials design (1.91), use of ICT (2.09) or locating resources (2.24). The document provided by the educational authority as a Guide for Language assistants (Consejería de Educación, 2013) is an attempt to cater for those aspects included in the above-mentioned orders. Besides some basic information about the Spanish educational system and practical orientation on bank accounts, health assistance and lodging, it also includes some ideas for the foreign language classroom mainly regarding the exploitation of authentic materials.

\subsection{Teaching resources}

Teaching resources are generally considered an essential factor to a successful implementation of bilingual programmes. To name but one example, in a similar study on CLIL in the Basque Autonomous Community "the need to be supported by didactic materials that can answer to the needs of the students involved" (Muñoa, 2011: 295) was ranked second out of four key factors needed for a positive implementation of CLIL programmes. 
Table III. Percentage of frequency of areas of investment and levels of satisfaction with provision of resources and published materials $(n=151) .1$ equals not important and

5 equals very important

\begin{tabular}{|c|c|c|c|c|c|c|c|}
\hline \multicolumn{8}{|c|}{ Areas of investment } \\
\hline & 1 & 2 & 3 & 4 & 5 & Mean & $\begin{array}{l}\text { Standard } \\
\text { Deviation }\end{array}$ \\
\hline Buy ICT resources & 3 & 18 & 29 & 26 & 24 & 3.51 & 1.10 \\
\hline Buy teaching material & 3 & 12 & 31 & 27 & 27 & 3.64 & 1.08 \\
\hline Require support staff & 4 & 7 & 9 & 53 & 27 & 4.15 & 1.11 \\
\hline Finance international school links & 2.5 & 2.5 & 12 & 27 & 56 & 4.32 & 0.96 \\
\hline \multicolumn{8}{|c|}{ Level of satisfaction with provision of resources } \\
\hline & 1 & 2 & 3 & 4 & 5 & Mean & $\begin{array}{l}\text { Standard } \\
\text { Deviation }\end{array}$ \\
\hline Have the resources provided been enough? & 19 & 32 & 32 & 15 & 2 & 2.5 & 1.03 \\
\hline Have the resources provided been useful? & 8 & 10 & 21 & 33 & 28 & 3.61 & 1.20 \\
\hline \multicolumn{8}{|c|}{ Level of satisfaction with published materials } \\
\hline & 1 & 2 & 3 & 4 & 5 & Mean & $\begin{array}{l}\text { Standard } \\
\text { Deviation }\end{array}$ \\
\hline Useful & 5 & 13 & 39 & 36 & 7 & 3.26 & 0.96 \\
\hline Sufficient & 13 & 30 & 42 & 13 & 2 & 2.61 & 0.94 \\
\hline Appropriate & 8 & 19 & 46 & 25 & 2 & 2.94 & 0.92 \\
\hline Innovative & 15 & 32 & 34 & 18 & 1 & 2.58 & 0.98 \\
\hline Affordable & 9 & 25 & 44 & 20 & 2 & 2.79 & 0.91 \\
\hline
\end{tabular}

In our survey in Castile and León, the four proposed areas of investment -ICT resources, teaching materials, support staff and international links- are highly rated: $3.91(\mathrm{n}=151, \mathrm{Sd}$. 0.66). The vast majority of teachers find international links, including school liaisons and stays abroad, the most valued investment to support bilingual school projects (4.32) since they provide a source of inspiration, reference models for good teaching practice, patterns of authentic linguistic input for classroom English, and subject content vocabulary, while they serve the ultimate goal of international communication. Thus, if in the recent past knowing the language was the prerequisite for international communication, today international links are seen as part of a journey involving learning in context, from and with partner institutions. This reflects the holistic view depicted in the 4Cs Framework, which establishes a symbiotic relationship between content, communication, cognition and culture, aiming at their integration and dynamic interaction (Coyle, Hood and Marsh, 2010). 
CLIL also demands catering for diversity, designing adequate materials and coordinating the contents and language with both teachers of non-linguistic subjects and teachers of English, which means an extra workload if compared with standard ELT. This may be lightened through the involvement of support staff, as reflected in the results of the questionnaire (4.15). The fact that ICT resources are not so highly valued (3.51) is consistent with the educational authorities having prioritized their investment in ICT in schools in recent years (Order EDU/1465/2010) through institutional strategies like "Red XXI EducaCyL Digital" to promote 2.0-equipped schools where interactive whiteboards, laptops and digital resources have become part of the school landscape.

Even so, in their answer to the first question of the second section of table III, teachers express their need for further resources: $51 \%$ find that the resources allocated for bilingual programmes on the part of the administration are not enough. However, if and when provided, two thirds of the teachers find them useful.

The questionnaire also asks teachers to rate the resources created by the publishing houses for the bilingual programmes. The average result of this dimension -2.83 ( $n=151$, Sd. 0.78) - and the answers provided by teachers show their lack of enthusiasm towards published materials for CLIL. They certainly admit their usefulness (3.26) but at the same time teachers feel their range is not very wide (2.61) and they are perceived as neither particularly innovative (2.58) nor affordable (2.79). This seems to correlate with teachers' heightened critical awareness and with their perceived need and growing ability to design materials suitable to their purpose. The challenge is twofold, for "the language input needs to be simple enough and presented in a reader-friendly manner so as to facilitate comprehension, while at the same time being sufficiently content-rich and cognitively challenging to capture students' interests" (Mehisto, Marshs and Frigols, 2008: 22). Most interestingly, even when a vast majority of teachers wish for the educational authorities to make a clear commitment to the programme in terms of economic investment, they also assume their share of personal responsibility, knowing they are part of the success of the novel approach, and therefore do not seem to claim that this rests exclusively on either the amount or the quality of commercially available materials. They complain that textbooks are sometimes a mere translation of the Spanish materials into English, and find a lack of appropriately adapted multi-media resources, but they also assert the relevance of their own professional presence and teaching performance in the classroom as the main and best resource, on which they base their argument to demand a greater institutional effort in their formation. Teaching in a bilingual project involves, therefore, not only using tailor-made resources but also introducing new methods which affect organisational issues such as pupils' groupings, coordination between teachers, teamwork, and more project-oriented teaching styles.

One enthusiastic teacher, for example, provided a narrative on the way she involves her students in research activities: "I design my own CLIL materials, using the text book as a starting point, in combination with other resources such as software (Audacity) to listen and self-assess their own oral recordings; pdf uploads, video links and other learning materials through the institutional Moodle platform. I exchange findings with other pupils through a SOFT (space odyssey for teenagers) e-twinning project, to which I have contributed self-made resources. I use NASA-produced educational materials, and I am involved in two European programmes to impart STEM subjects (Science, Technology, Engineering and Maths) at primary and secondary levels". 


\subsection{Evaluation of the project}

The last section of the questionnaire serves to assess the overall perception of teachers on the global value of bilingual sections for students, teachers and schools, but it does not account for measurable linguistic outcomes. The results of the survey are utterly conclusive.

Table IV. Percentage of frequency of the overall evaluation of the bilingual project $(n=151) .1$ equals not important and 5 equals very important

\begin{tabular}{|l|c|c|c|c|c|c|c|}
\hline & $\mathbf{1}$ & $\mathbf{2}$ & $\mathbf{3}$ & $\mathbf{4}$ & $\mathbf{5}$ & Mean & $\begin{array}{c}\text { Standard } \\
\text { Deviation }\end{array}$ \\
\hline The bilingual project is good for the student & 0 & 1 & 7 & 34 & 58 & 4.49 & 0.68 \\
\hline The bilingual project is good for the teachers & 3.5 & 3.5 & 19 & 34 & 40 & 4.03 & 1.00 \\
\hline The bilingual project is good for the school & 1 & 1 & 10 & 32 & 56 & 4.42 & 0.75 \\
\hline
\end{tabular}

The overall evaluation of the bilingual sections is remarkably positive, and offers no doubt as to the gains of the project: $92 \%$ of the teachers who have completed the questionnaire consider it beneficial or very beneficial for the students, and $88 \%$ think it is good for the school; 74\% consider it good for teachers, a lower percentage that in the light of the whole picture depicted by the survey can be interpreted as a reflection of the toll it may take on the teachers involved.

In their qualitative comments they highlight two drawbacks, namely, the added difficulty of catering for inclusive alternatives for SEN children and the need to become fully confident and proficient in their use of English. Accreditation for bilingual teaching poses an unanticipated threat for the non-specialists whose profile may be seen, in comparison, as downgraded, less prestigious and less competitive. On the whole, teachers wish they could count on the whole support of education authorities in terms of allocation of human and material resources, opportunities for Continuing Professional Development, and flexible arrangements like splitting the larger classes into smaller groups.

Most teachers agree there is still a long way ahead of them but the following comments from teachers will suffice to illustrate their most positive assessment of the project: "it has made the whole school hold a more open attitude"; "it prepares pupils much better for a pluralistic society"; "it brings unprecedented challenges to the whole school and, because of them, a greater cohesion and a stronger sense of community"; "it has raised not only the school standards but the esteem of parents, who are proud of their children's progress"; "we find it difficult to believe: middle to lower-class families are getting in touch with partner families abroad and not just the school but the whole village is also getting enriched thanks to these cultural exchanges". In short, and in the words of one teacher: "In the schools where most of the teachers got involved in the development of the bilingual programme there has been a great change: students have established new groupings, spaces have been redistributed, new activities and resources have been created and greater and deeper levels of cooperation among teachers have emerged". 


\section{Conclusion}

The CLIL approach is stretching some commonly assumed practices and theories of teaching and of second language acquisition beyond their boundaries to the extent that the concept of method itself is being challenged and suggestions have been made to replace it with the pedagogic parameters of particularity, practicality and possibility as organizing principles for L2 teaching and teacher education (Wiesmes, 2009). These run parallel to the need of situating, finding concrete applications and setting the conditions for an effective adoption of CLIL in mainstream education.

After seven years of implementation, we trust our findings may throw light upon the three seminal dimensions of the bilingual project in Castile and León we have explored, which clearly intersect. In the first place, teachers participating in CLIL programmes consider that they need further training regardless of the intensity or quality of their initial training. Teachers start by stressing the importance of reaching a proficient level of language, but once they feel comfortable with the use of classroom and content English, they give priority to methodological concerns and express the need to participate in other Continuing Professional Development schemes and further their training to make the most of their own potential and that of their assistant teachers, whose number is considered scarce. And as we witness a transition between today's teaching workforce and the new cohort of teachers who will enter the profession having had CLIL experiences as students, upgrading teacher education programmes will be even more necessary (Coyle, Hood, and Marsh, 2010).

Secondly, together with life-long learning provision, teachers express their need for more and better resources, even if both their quality and relevance are being redefined in terms of their suitability to specific teaching purposes, their appropriateness to the context, their degree of multimodality, and their integration within networks of collaboration at a local, regional and international level through institutional liaisons across disciplinary and geographical boundaries. International links are considered an extremely valued investment to support bilingual school projects. Selecting, designing, adapting, and exploiting ICT and other resources are essential but also time-consuming and that burden, teachers claim, should be lightened with support staff or by allotting them slots of time within their timetable to that end.

Thirdly and finally, in spite of their own shortages at the level of regional administrative support, the overall positive perception of teachers regarding the bilingual project, with $92 \%$ of them finding it beneficial or very beneficial for the students, shows a steady progress in bridging the gap between local grass-root teaching performance and the EU policy aiming at the creation of a multilingual citizenship in Europe

Castile and León's Education Department has set itself the goal of reaching 500 bilingual sections at work by the year 2015. It lies within its own responsibility to match this figure with parallel measures for quality assurance. More and more diversified training and lifelong learning opportunities, fewer students to cater for more personalised teaching and greater levels of coordination for collaborative planning, performing, assessing and reporting on the teaching of both content and foreign language are seen as pivotal aspects around which any bilingual project should revolve, which demand further specific studies.

A fair, transparent, in-depth and independent regional evaluation, similar to the one funded jointly by the Spanish Ministry of Education and the British Council (Dobson et al., 
2010), would complement, confirm, nuance and enrich the teachers' voices we have brought to the fore, important as they are. Above all, it would objectify and throw a much clearer light upon some of the insights gathered from our survey into the current state of bilingual education in Castile and León as a preliminary step to set in motion the most appropriate policies for the provision of high quality bilingual education in the next decade.

\section{Bibliographical REFERENCES}

Boldizsár, G. (2003). An Introduction to the current European context in language teaching. Strasbourg: European Centre for Modern Languages.

Bruton, A. (2011). "Is CLIL so beneficial, or just selective? Re-evaluating some of the research", in System 39 (4): 523-532.

Consejería de Educación. (2010). Guía de Estudios y Centros Educativos de Castilla y León 2010/2011. Valladolid: Junta de Castilla y León.

Consejería de Educación. (2013). Guía para los auxiliares de conversación 2013/2014 en Castilla y León. Valladolid: Junta de Castilla y León.

Consejo Escolar de Castilla y León. (2013). Informe del Sistema Educativo en Castilla y León. Curso 2011-2012. Valladolid: Consejería de Educación. Junta de Castilla y León.

Consejo Escolar de la Comunidad de Madrid. (2013). Madrid, a Bilingual Community. Madrid: Consejería de Educación, Juventud y Deporte de la Comunidad de Madrid.

Coyle, D., Hood, P. and Marsh, D. (2010). CLIL: Content and Language Integrated Learning. Cambridge: Cambridge University Press.

Dobson, A., Pérez, Ma. D. and Johnstone, R. (2010). Bilingual Education Project (Spain): Evaluation Report. Madrid: British Council, Spain/Ministerio de Educación.

Dobson, A., Pérez, Ma. D. and Johnstone, R. (2011). Bilingual Education Project (Spain) Evaluation Report Online Supplement. Madrid: British Council, available from http://www. mecd.gob.es/educacion-mecd, accessed 29 May, 2014.

Durán, R. and Beltrán, F. (2013). "Nuevos modelos de formación del profesorado de inglés: el caso de Castilla y León", in Profesorado: Revista de curriculum y formación del profesorado 17 (3): 307-323, available from http://www.ugr.es/recfpro, accessed 29 May, 2014.

Eurydice. (2006). Content and Language Integrated Learning (CLIL) at School in Europe. Brussels: Eurydice European Unit.

Fernández, R. and Halbach, A. (2011). "Analysing the Situation of Teachers in the Madrid Bilingual Project after Four Years of Implementation", in Y. Ruiz de Zarobe, J. Manuel Sierra and F. Gallardo del Puerto (eds.), Content and Foreign Language Integrated Learning. Contributions to Multilingualism in European Contexts. Bern: Peter Lang, 41-70.

Fernández, R., Pena, C., García, A. and Halbach, A. (2005). "La Implantación de Proyectos Educativos Bilingües en la Comunidad de Madrid: las Expectativas del Profesorado antes de Iniciar el Proyecto", in Porta Linguarum 3: 161-173, available from http://www.ugr. es/portalin, accessed 29 May, 2014.

House, S. (2007). "CLIL: A new model for language teaching", in R. Durán Martínez and S. Sánchez-Reyes (eds.), El componente lingüístico en la didáctica de la lengua inglesa. Salamanca: Ediciones Universidad de Salamanca, 123-129.

Laorden, C. and Peñafiel, E. (2010). "Proyectos bilingües en los centros de la Comunidad Autónoma de Madrid: Percepción de los equipos directivos", in Revista de Investigación Educativa 28 (2): 325-344. 
Lasagabaster, D. and Ruiz de Zarobe, Y. (eds.) (2010). CLIL in Spain: Implementation, results and teacher training. Cambridge: Cambridge Scholars Publishing.

Lorenzo, F., Casal, S. and Moore, P. (2009). "The Effects of Content and Language Integrated Learning in European Education: Key Findings from the Andalusian Bilingual Sections Evaluation Project", in Applied Linguistics 31 (3): 418-442.

Lova Mellado, Ma ., Bolarín Martínez, Mª J. and Porto Currás, M. (2013). "Programas bilingües en Educación Primaria: Valoraciones de Docentes", in Porta Linguarum 20: 253-268, available from http://www.ugr.es/portalin, accessed 29 May, 2014.

Mehisto, P., Marsh, D., and Frigols, Mª. J. (2008). Uncovering CLIL: Content and Language Integrated Learning in Bilingual and Multilingual Education. Oxford: Macmillan Education.

Muñoa, I. (2011). "Key Factors to be Considered by CLIL Teachers", in Y. Ruiz de Zarobe, J. Manuel Sierra and F. Gallardo del Puerto (eds.), Content and Foreign Language Integrated Learning. Contributions to Multilingualism in European Contexts. Bern: Peter Lang, 239-314.

Pavón, V. and Rubio, F. (2010). "Teachers' Concerns and Uncertainties about the Introduction of CLIL Programmes", in Porta Linguarum 14: 45-58, available from http://www.ugr.es/ portalin, accessed 29 May, 2014.

Pena, C. and Porto, Ma. D. (2008) "Teacher beliefs in a CLIL education project", in Porta Linguarum 10: 151-161, http://www.ugr.es/portalin, accessed 29 May, 2014.

Wiesmes, R. (2009). "Developing Theories of Practices in CLIL: CLIL as Post-method Pedagogies?", in Y. Ruiz de Zarobe and R. $\mathrm{M}^{\mathrm{a}}$. Jiménez Catalán (eds.), Content and Language Integrated Learning. Evidence from Research in Europe. Bristol: Multilingual Matters, 41-59.

\section{Legal References}

España. Orden EDU/1465/2010, de 4 de junio, por la que se crea el distintivo de calidad Sello Escuela 2.0. BOE N. 138. 07/06/2002.

Castilla y León. Orden EDU 6/2006, de 4 de enero, por la que se regula la creación de secciones bilingües en centros sostenidos con fondos públicos de la Comunidad de Castilla y León. BOCYL N. 8. 12/01/2006.

Castilla y León. Orden EDU/1847/2007, de 19 de noviembre, por la que se modifica la Orden EDU/6/2006, de 4 de enero por la que se regula la creación de secciones bilingües en centros sostenidos con fondos públicos de la Comunidad de Castilla y León. BOCYL N. 228. 23/11/2007.

Castilla y León. Orden EDU/1134/2011, de 6 de septiembre, por la que se regula la actividad de los auxiliares de conversación seleccionados por el Ministerio de Educación en centros educativos de la Comunidad de Castilla y León. BOCYL N. 178. 14/11/2011.

Castilla y León. Orden EDU/392/2012, de 30 de mayo, por la que se modifica la Orden EDU/6/2006, de 4 de enero, por la que se regula la creación de secciones bilingües en centros sostenidos con fondos públicos de la Comunidad de Castilla y León. BOCYL N. 109. 08/06/2012.

Castilla y León. Resolución de 7 de noviembre de 2013, de la Dirección General de Recursos Humanos, de la Consejería de Educación, por la que se convoca, en el curso 2013/2014, la acreditación de la competencia lingüística en lenguas extranjeras del profesorado funcionario e interino de los Cuerpos de Maestros, Catedráticos y Profesores de Enseñanza Secundaria y Profesores Técnicos de Formación Profesional. BOCYL N 221. 15/11/2013.

Castilla y León. Orden EDU/154/2013, de 13 de marzo, por la que se establece de oficio la puesta en funcionamiento de secciones bilingües en centros públicos y se autoriza la creación de secciones bilingües en centros privados concertados para el curso 2013/2014. BOCYL N. 58. 25/03/2014. 
Castilla y León. Orden EDU/277/2014, de 14 de abril, por la que se modifica la Orden EDU/1134/2011, de 6 de septiembre, por la que se regula la actividad de los auxiliares de conversación seleccionados por el Ministerio de Educación en centros educativos de la Comunidad de Castilla y León. BOCYL N. 79. 28/04/2014. 